\title{
Hay or silage? How the forage preservation method changes the volatile compounds and sensory properties of Caciocavallo cheese
}

\author{
F. Serrapica, ${ }^{1}$ P. Uzun, ${ }^{1}$ F. Masucci, ${ }^{1 *}$ * F. Napolitano, ${ }^{2} \odot$ A. Braghieri, ${ }^{2} \odot$ A. Genovese, ${ }^{1} \odot$ R. Sacchi,,${ }^{1} \odot$ \\ R. Romano, ${ }^{1}$ C. M. A. Barone, ${ }^{1}$ (1) and A. Di Francia ${ }^{1}$ (D) \\ ${ }^{1}$ Dipartimento di Agraria, Università degli Studi di Napoli Federico II, via Università 100, 80055 Portici (Napoli), Italy \\ ${ }^{2}$ Scuola di Scienze Agrarie, Forestali, Alimentari ed Ambientali, Università degli Studi della Basilicata, via dell'Ateneo Lucano 10, 85100 Potenza, \\ Italy
}

\section{ABSTRACT}

The aim of this study was to determine the effect of the forage preservation method (silage vs. hay) on volatile compounds and sensory properties of a traditional Caciocavallo cheese during ripening. A brown-midrib sudangrass hybrid was cultivated on a 7-ha field and at harvesting it was half ensiled in plastic silo bags and half dried to hay. Forty-four lactating cows were equally allotted into 2 groups fed a isonitrogenous and isoenergetic total mixed ration containing as the sole forage either sorghum hay (H group) or sorghum silage (S group). Milk from the 2 groups was used to produce 3 batches/diet of Caciocavallo ripened for 30, 60 , and $90 \mathrm{~d}$. Milk yield and composition as well as cheese chemical and fatty acid composition were not markedly affected by the diet treatment and ripening time. By contrast, ripening induced increased levels of the appearance attribute "yellowness," along with the "overall flavor," the odor/flavor attributes "butter" and "hay," the "salty," "bitter," and "umami" tastes, and the texture attribute "oiliness," whereas the appearance attribute "uniformity" and the texture attribute "elasticity" were reduced. The silage-based diet induced higher perceived intensities of several attributes such as "yellowness"; "overall flavor"; "butter"; "grass" and "hay" odor/flavors; "salty," "bitter," and "umami" tastes; and "tenderness" and "oiliness" textures. In S cheese we also observed higher amounts of ketones and fatty acids. Conversely, $\mathrm{H}$ cheese showed the terpene $\alpha$-pinene, which was not detected in $\mathrm{S}$ cheese, and a higher intensity of the appearance attribute "uniformity." These differences allowed the trained panel to discriminate the products, determined an increased consumer liking for 90-d ripened cheese, and tended to increase consumer liking for hay cheese.

Received June 25, 2019.

Accepted October 14, 2019

*Corresponding author: masucci@unina.it
Key words: forage preservation method, Caciocavallo cheese, cheese sensory property, volatile compound

\section{INTRODUCTION}

Cheese quality is mainly dependent on technological process (e.g., manufacturing, ripening time, and cheese factory conditions) and chemical and microbiological characteristics of raw milk (Fox et al., 2017), which in turn are influenced by several upstream factors including cow feeding (Martin et al., 2005). In particular, the forage component of cow diet is able to convey specific organoleptic and nutritional features to milk products, and therefore really contributes to define "terroir" as well as sensory and healthy attributes of dairy products (Giaccone et al., 2016; Mordenti et al., 2017).

Caciocavallo is a traditional semi-hard pasta filata cheese typically produced in up-land southern Italy in artisanal small factories or on farm, using milk obtained from animals fed with a combination of concentrate, pasture, and preserved forages according to the seasonal variations of forage availability. Within the forage preservation methods, ensiling appears to be a more flexible and economic option compared with hay, especially in mountain areas where unfavorable weather conditions prevail (Borreani et al., 2007; Freschi et al., 2015). However, poorly preserved and improperly managed ensiled forages can develop unwanted spoilage microorganisms that trigger a nutritive value reduction and even impair the quality of milk and dairy products, especially of ripened cheeses. As a consequence, the use of ensiled forages within the quality labeled cheese channels is still debated (Driehuis et al., 2018). In addition, even well-preserved silages per se can influence the composition and sensory profile of cheeses (Stefanon and Procida, 2004; Martin et al., 2009; Cosentino et al., 2016). In recent years, interest has been growing in milk and dairy products produced excluding silages from cows' diets (Paredes et al., 2018), so that "silagefree" products have recently been included into the 
Traditional Specialties Guaranteed (TSG) register as "Haymilk" or made from "Haymilk" (European Commission, 2016).

As no protection of the general designation Caciocavallo has been implemented and different cheeses, independent from the feeding system, are currently marketed under this common name (Piraino et al., 2005), a possible differentiation and quality assurance strategy for Caciocavallo cheese may be the TSG label "Haymilk."

Although a certain number of studies examined the effects of silage feeding on milk and cheese characteristics (see the reviews by Martin et al., 2005; Kalač and Samková, 2010; Kalač, 2011; Khan et al., 2015), only one of them addressed this issue while minimizing the confounding factors of forage source and cheese manufacture (Verdier-Metz et al., 1998). However, no studies addressed Caciocavallo cheese and the effect on consumer liking in particular.

Therefore, following up a previous study describing the taxonomic structure of the microbiota of the milk and the dynamic of bacterial communities during Caciocavallo cheese-making and ripening (Giello et al., 2017), we aimed to compare, at different ripening times, the chemical, instrumental, and sensory properties of a Caciocavallo cheese produced by using hay or silage as sole forage source, and their relationship with consumer liking.

\section{MATERIALS AND METHODS}

\section{Feeds, Animals, and Cheese-Making Procedure}

The study was carried out in a dairy cattle farm (70 Italian Friesian cows, 50 ha of usable agricultural area) located in internal Apennine mountains of Campania, a region of southern Italy $\left(41^{\circ} 16^{\prime} \mathrm{N} 15^{\circ} 05^{\prime} \mathrm{E}\right)$. The farm produces a traditional food product named Caciocavallo di Castelfranco (Italian Ministry of Agricultural, Food and Forestry Policies, Ministerial Decree no. 11262/2018) at a small-scale artisan cheese-making facility. On May 2014, a 7-ha dryland field ( $760 \mathrm{~m}$ above sea level) was sown with a brownmidrib sudangrass hybrid for silage and hay production [Hermes, Padana Sementi Elette s.r.l, Tombolo, PD, Italy; Sorghum sudanense $\times$ Sorghum sudanense (Piper) Stapf.]. The agro-meteorological conditions, soil characteristics, and crop management practices have been described elsewhere (Uzun et al., 2018b). The forage was mowed on August 2014 at the late boot stage [i.e., growth stage 5 to 6 according to Vanderlip and Reeves (1972)], and one half (3.5 ha) was chopped at a theoretical length of $1.1 \mathrm{~cm}$ and ensiled without any additives using a 2.7-m-diameter plastic silo bag
(Boschi Servizi s.r.l., Villanova di Ravenna, RA, Italy), whereas the other half was air-dried to hay and then harvested in 1.2-m-diameter round bales stored in a covered barn. Neither silage nor hay were rained on. In March 2015, a 13-d-long feeding trial was undertaken. Forty-four lactating cows were randomly allocated into 2 groups, silage $(\mathbf{S})$ and hay $(\mathbf{H})$, balanced for DIM (169 \pm 116 vs. $165 \pm 109$ d, respectively, for the $\mathrm{S}$ and $\mathrm{H}$ group), milk yield $(23.4 \pm 8.2$ vs. $23.7 \pm 7.4 \mathrm{~kg} /$ head per d), and quality (fat $4.4 \pm 0.8$ vs. $4.5 \pm 0.9 \%$; protein $3.4 \pm 0.5$ vs. $3.6 \pm 0.4 \%)$; values shown are mean \pm standard deviation. The groups were housed in 2 adjacent freestall pens located in the same barn and were milked twice daily (0500 and $1700 \mathrm{~h}$ ). The $\mathrm{H}$ group was fed a TMR containing as the sole forage the sorghum hay that, for the S group, was replaced by the sorghum silage. A limited quantity of sorghum hay (5.4 $\mathrm{kg}$ as fed) was included in the silage-based TMR to provide a basic level of physically effective fiber and minimize the risk of ruminal acidosis. The forage species, the commercial concentrate, and the forage to concentrate ratio were similar to those usually used in the area of production of Caciocavallo di Castelfranco. Details of experimental forages and diets are given in Table 1 . The rations were fed once daily $(0900 \mathrm{~h})$ in an amount to provide approximately $10 \%$ orts for ad libitum consumption and were re-approached several times daily. Feed intake was daily measured by the difference between feed offered and orts $(23.6 \pm 1.1$ and $24.5 \pm 0.4 \mathrm{~kg}$ of $\mathrm{DM} / \mathrm{d}$, respectively, for the $\mathrm{H}$ and $\mathrm{S}$ groups). After $10 \mathrm{~d}$ of adaptation to the diets, during 3 consecutive morning milkings, bulk milk of each group was separately collected and Caciocavallo cheeses from $\mathrm{H}$ and $\mathrm{S}$ milk were manufactured at the same time in separate vats using the identical traditional procedure as described in details by Giello et al. (2017). Briefly, raw milk was gently heated $\left(38^{\circ} \mathrm{C}\right)$ and then inoculated with natural whey culture from the previous cheesemaking day, and coagulated by liquid calf rennet $(80 \%$ chymosin, $20 \%$ pepsin; Linea rossa, Caglificio Clerici S.p.a., Cadorago, Como, Italy). When curd reached proper consistency (after about $30 \mathrm{~min}$ ), the coagulum was cut into 6 - to $8-\mathrm{mm}$ particles, the whey was partially removed, and the fresh curd was left to acidify under heated whey until $\mathrm{pH}$ decreased enough to allow curd texturing. An artisanal stretchability test, as described in Uzun et al. (2019), was performed to check the ability of curd for texturing. The manual stretching was carried out in hot water and the curd was molded into the typical flask-like shape with a short neck and a small, round top. Finally, the cheeses were cooled in water, salted in brine $(25 \% \mathrm{NaCl}$ for about $12 \mathrm{~h})$, and left to ripen in a cellar at 16 to $17^{\circ} \mathrm{C}$ and 60 to $70 \%$ relative humidity. 
Three batches of Caciocavallo were produced for each diet (average cheese yield 10\%), all consisting of 12 cheeses with an average weight of $2.0 \mathrm{~kg}$.

\section{Sampling Procedure and Chemical and Instrumental Analyses}

In each cheese making day, samples of sorghum silage, sorghum hay and TMR were collected to determine DM, $\mathrm{CP}$, ether extract, ash (AOAC International, 2002), soluble protein, NPN (Licitra et al., 1996), NDF, ADF, and ADL (Van Soest et al., 1991). Starch content was determined by the polarimetric method described by the international standard ISO 6493 (ISO, 2000). Concentration of $\mathrm{NE}_{\mathrm{L}}$ of the diets was calculated according to Sauvant and Nozière (2013). Moreover, milk yield of each cow was recorded during the morning milking by means of recorder jars and 2 samples of bulk milk from each vat were collected just before cheese-making, packed under refrigeration in 200-mL plastic flasks, and sent to the laboratory for immediate determination of fat, protein, and lactose (Milkoscan 605, Foss Electric, Hillerød, Denmark).

Chemical and instrumental analyses of Caciocavallo cheeses were determined at 30, 60, and $90 \mathrm{~d}$ of ripening. Two cheeses for each batch of production and ripening time were analyzed. The chemical composition and the fatty acid profile were determined on grated cheese taken at $2 \mathrm{~cm}$ from the rind. Moisture, protein, and fat contents were measured by oven drying, Kjeldahl, and Gerber methods, respectively (AOAC International, 2002). Extraction of fat and the subsequent GC analysis to determine fatty acid composition were performed as previously described by Romano et al. (2011).

Instrumental color and texture were measured on cylindrical (diameter, $23 \mathrm{~mm}$; height, $11 \mathrm{~mm}$ ) samples taken from the upper, central, and lower parts of a cheese slice, and the mean values were used for statistical analysis. Color was determined according to the CIELAB system by a U-3000 spectrophotometer (Hitachi, Tokyo, Japan), and yellow index (YI) was calculated according to Francis and Clydesdale (1975). The compression test was performed by an Instron Universal 5565 testing machine (Instron Ltd., High Wycombe, UK). The velocity and the load cell were $50 \mathrm{~mm} / \mathrm{min}$ and $500 \mathrm{~kg}$, respectively, and each sample underwent 2 cycles of $50 \%$ compression.

\section{Sensory Analysis and Consumer Liking}

The sensory analysis was carried out at 30,60, and $90 \mathrm{~d}$ of ripening by using a quantitative descriptive analysis (QDA) method (Murray et al., 2001). A panel composed of 8 assessors participated in the analysis. All panelists were experienced in the sensory analysis of pasta filata cheeses, trained in the assessment of the intensity of sensory stimuli and involved in the development of the attributes to generate a specific vocabulary

Table 1. Ingredients and chemical composition (means and SD of 3 samples collected over the cheese making period) of the forages and the TMR fed to dairy cows ${ }^{1}$

\begin{tabular}{|c|c|c|c|c|}
\hline Item & $\begin{array}{l}\text { Sorghum } \\
\text { hay }\end{array}$ & $\begin{array}{l}\text { Sorghum } \\
\text { silage }\end{array}$ & S-TMR & H-TMR \\
\hline \multicolumn{5}{|l|}{ Ingredient, $\mathrm{kg}$ as fed } \\
\hline Sorghum hay & - & - & 5.4 & 12.7 \\
\hline Sorghum silage & - & - & 26.5 & - \\
\hline Concentrate $^{2}$ & - & - & 13.0 & 13.3 \\
\hline Water & - & - & - & 16.8 \\
\hline Vitamin and mineral mix & - & - & 0.40 & 0.40 \\
\hline $\mathrm{DM}, \mathrm{kg}$ & - & - & 22.7 & 22.7 \\
\hline Forage, $\%$ of DM & - & - & 52.4 & 51.2 \\
\hline \multicolumn{5}{|l|}{ Chemical composition } \\
\hline DM, \% & $91.5(0.48)$ & $26.3(0.56)$ & $50.6(0.43)$ & $53.0(0.38)$ \\
\hline $\mathrm{NE}_{\mathrm{L}}, \mathrm{MJ} / \mathrm{kg}$ of $\mathrm{DM}$ & $4.06(0.06)$ & $4.22(0.05)$ & $6.00(0.01)$ & $6.00(0.01)$ \\
\hline Ether extract, $\%$ of DM & $2.0(0.15)$ & $2.8(0.13)$ & $4.0(0.05)$ & $3.8(0.03)$ \\
\hline $\mathrm{CP}, \%$ of $\mathrm{DM}$ & $7.1(0.16)$ & $8.8(0.20)$ & $16.8(0.11)$ & $16.2(0.14)$ \\
\hline Ash, \% of DM & $10.2(0.22)$ & $9.8(0.13)$ & $8.3(0.17)$ & $8.1(0.17)$ \\
\hline $\mathrm{NDF}, \%$ of DM & $61.0(0.25)$ & $57.3(0.65)$ & $39.5(0.57)$ & $40.1(0.21)$ \\
\hline $\mathrm{ADF}, \%$ of $\mathrm{DM}$ & $40.8(0.25)$ & $37.8(0.50)$ & $24.8(0.23)$ & $25.4(0.42)$ \\
\hline Starch, \% of DM & $2.1(0.02)$ & $3.00(0.07)$ & $19.3(0.13)$ & $19.4(0.26)$ \\
\hline $\mathrm{SP}^{3} \%$ of $\mathrm{DM}$ & $2.20(0.09)$ & $4.5(0.10)$ & $5.4(0.36)$ & $4.8(0.48)$ \\
\hline NPN, \% of DM & $0.29(0.03)$ & $0.58(0.06)$ & $0.68(0.03)$ & $0.60(0.03)$ \\
\hline
\end{tabular}

${ }^{1} \mathrm{H}-\mathrm{TMR}=$ diet containing sorghum hay as sole forage source; S-TMR $=$ diet containing sorghum silage as main forage source (59\% as fed).

${ }^{2}$ Commercial concentrate based on maize meal, soybean meal, sunflower meal, beet pulp, barley meal, wheat flour shorts, flaked maize, and hydrogenated palm fat.

${ }^{3} \mathrm{SP}=$ soluble protein. 
Table 2. Descriptive attributes and definitions used to evaluate Caciocavallo cheese

\begin{tabular}{ll}
\hline Descriptor & Definition \\
\hline $\begin{array}{l}\text { Appearance } \\
\text { Yellow } \\
\text { Uniformity }\end{array}$ & $\begin{array}{l}\text { Overall intensity of yellow color } \\
\text { Odor/flavor } \\
\text { Overall odor }\end{array}$ \\
$\begin{array}{l}\text { Overall flavor } \\
\text { Milk }\end{array}$ & Overall intensity of the odor \\
Butter & Odor/lflavor arising from milk at room temperature \\
Grass & Odor/flavor arising from butter at room temperature \\
Hay & Fundamental taste of fresh grass \\
Taste & Fundamental taste of dry grass \\
Salty & Fundamental taste associated with sodium chloride \\
Bitter & Fundamental taste associated with quinine \\
Umami & Fundamental taste elicited by certain peptides and nucleotides \\
Texture & Minimum force required to chew cheese sample: the lower the force, the higher the tenderness \\
Tenderness & Degree to which the product will return to its original shape after being compressed between the teeth \\
Elasticity & Perception of the amount of fat released by the product during mastication \\
Oiliness & \\
\hline
\end{tabular}

for Caciocavallo cheese as suggested by Albenzio et al. (2013). A single score card with 2 appearance, 6 odor/ flavor, 3 taste, and 3 texture descriptors was compiled, representing the consensus profile of sensory characteristics (Table 2).

In all tests, carried out at about $1000 \mathrm{~h}$, cheese cube samples $\left(1 \mathrm{~cm}^{3}\right)$ were served in a randomized order. A random 3-digit number was assigned to each sample so that panelists were unable to recognize the treatment. Attributes were evaluated by rating the samples on 100-mm unstructured lines (0-20 mm weak, 21-40 $\mathrm{mm}$ weak/moderate, $41-60 \mathrm{~mm}$ moderate, $61-80 \mathrm{~mm}$ moderate/strong, 81-100 mm strong intensity). Tests were performed in sensory booths (ISO 8589; ISO, 1998) under red fluorescent lights to mask color differences in the samples, except during the evaluation of color, when white fluorescent lighting was used. A slice of apple was provided to neutralize taste between cheese samples. To avoid sensory fatigue due to the number of samples, in each session, only 3 samples were evaluated. The interval between samples was approximately $10 \mathrm{~min}$. The panelists evaluated 3 replications of each of the 6 products ( 3 ripening times $\times 2$ diets) and completed their assessment in $6 \mathrm{~d}$.

Caciocavallo cheeses were also evaluated for consumer liking at 30,60, and $90 \mathrm{~d}$ of ripening (Kähkönen et al., 1996). A total of 75 consumers (46 females and 29 males) with an age ranging from 26 to $60 \mathrm{yr}$ participated in the test. Each participant evaluated six $1-\mathrm{cm}^{3}$ cheese cube samples (corresponding to the 3 ripening times $\times 2$ diets) in a controlled sensory analysis laboratory as described for QDA. For each product, consumers expressed an overall liking and a liking according to the following sensory inputs: appearance, taste/flavor, and texture. In total each consumer expressed 4 likings for each product. Consumers expressed their liking on a 9-point hedonic scale ranging from "extremely unpleasant" (1) to "extremely pleasant" (9) with a neutral point corresponding to "neither pleasant nor unpleasant" (5; Kähkönen et al., 1996).

\section{Cheese Volatile Organic Compounds Analysis}

Due to the lack of samples, the volatile organic compound analyses were carried out only at 30 and $60 \mathrm{~d}$ of ripening. The extraction and analysis of volatile organic compounds was performed using dynamic headspace solid-phase microextraction and $\mathrm{GC} / \mathrm{MS}$, according to Lee et al. (2003) and Genovese et al. (2019). The cheese samples at $-10^{\circ} \mathrm{C}$ were finely grated (about $1 \mathrm{~mm}$ ), and $22.5 \mathrm{~g}$ were put in a $100-\mathrm{mL}$ flask and then added with $25 \mathrm{~mL}$ of distilled water, $50 \mu \mathrm{L}$ of 2-methyl-3-heptanone (99\% purity; Sigma-Aldrich, St. Louis, MO) as internal standard, and $2.75 \mathrm{~g}$ of sodium phosphate (SigmaAldrich). The analysis was performed in triplicate.

\section{Statistical Analysis}

Statistical analysis was performed by using SAS package software version 8.1 (SAS Institute Inc., Cary, NC). Two-way ANOVA per repeated measures (Mixed procedure) was used to test the effect of diet on milk yield, with diet ( $\mathrm{S}$ and $\mathrm{H}$ ) as non-repeated factor, day of cheese manufacture (3 levels) as repeated factor, and cow variance as error term. One-way ANOVA (GLM procedure) was used to test the effect of diet (S and $\mathrm{H})$ on bulk milk composition. Data of chemical composition, instrumental color and texture, and volatile compounds of cheeses were analyzed by 2-way ANOVA (GLM procedure) to determine the fixed effects of diet ( $\mathrm{S}$ and $\mathrm{H})$, ripening time $(30,60$, and $90 \mathrm{~d})$, and their 
interaction (diet $\times$ ripening). A multiple comparison of means was performed using the Bonferroni test.

To assess the panel performance, data gathered from QDA were subjected to ANOVA using assessor (8 levels), replication (3 levels), product $(6$ levels $=2$ diets $\times 3$ ripening times), and their interactions as factors. A second ANOVA was conducted to assess the effects of $\operatorname{diet}(\mathrm{S}$ and $\mathrm{H})$, ripening time $(30,60$, and $90 \mathrm{~d})$ and their interaction as factors. A mixed ANOVA using assessor as random factor was conducted for the attributes "overall odor" and odor/flavor "milk" due to the fact that for these 2 descriptors the interactions assessor $\times$ product and assessor $\times$ replication were significant. Similarly, to identify the most liked product, liking scores were analyzed by ANOVA using diet ( $\mathrm{S}$ and $\mathrm{H})$, ripening time $(30,60$, and $90 \mathrm{~d})$, and their interaction as factors.

Partial least squares discriminant analysis was chosen as an exploratory technique to investigate the correlation between sensory properties and volatile organic compounds of Caciocavallo cheese in relation to diet and ripening. Partial least squares elaboration was carried out using XLStat (version 2009.3.02), an add-in software package for Microsoft Excel (Addinsoft Corp., Paris, France). All data are reported as least squares means and standard errors of means. Statistical significance was declared at $P \leq 0.05$.

\section{RESULTS AND DISCUSSION}

\section{Chemical Composition of Feeds, Milk, and Cheese}

The main differences in chemical and nutritive characteristics of $\mathrm{H}$ and $\mathrm{S}$ sorghum were for $\mathrm{CP}$, ether extract (higher in silage), and NDF (higher in hay; Table 1). Moreover, as expected, the ensiling increased nitrogen solubility so that higher values of NPN and PS were observed for S sorghum. As known, shattering of leaves, and the resultant reduction of protein and lipid, is usually much larger in hay-making than in ensiling. In addition, the exposition of forage to high temperature or dry-air during hay-making can result in a strong lipid reduction (Glasser et al., 2013). In spite of these potential risks, the quality of $\mathrm{H}$ sorghum was relatively little affected by the harvesting practices, as also observed by Villeneuve et al. (2013). This result suggest that any differences between cheese characteristics can be attributed to the preservation method per se (i.e., fermented vs. dry forage) rather than to different nutritional inputs. As reviewed by Coblentz and Akins (2018), few feeding trials have actually compared the same forage preserved as hay and silage, whereas previous studies make it difficult to identify the effects of forage preservation method on animal product qual- ity, due to the concurrence of other confounding factors such as differences in forage species (e.g., Verdier-Metz et al., 2005), growth stages (e.g., Borreani et al., 2007), or nutritional characteristics as a consequence of postharvesting damages (e.g., Hancock and Collins, 2006).

As also reported by other authors (Verdier-Metz et al., 1998; Martineau et al., 2007; Villeneuve et al., 2013), the dietary treatment did not affect milk yield $(26.8$ vs. $27.0 \pm 0.55 \mathrm{~kg} / \mathrm{d}, \mathrm{LSM} \pm \mathrm{SEM}$ respectively, for $\mathrm{S}$ and $\mathrm{H}$ group) and milk fat (4.07 vs. $4.27 \pm 0.08$ ). Nevertheless, milk protein was slightly but significantly higher in $\mathrm{H}$ milk ( 3.24 vs. $3.50 \pm 0.032 ; P<0.01$ ). This result, also observed by Verdier-Metz et al. (2005), may be due to a reduction of microbial protein synthesis in the rumen related to the higher solubility of protein of S sorghum (Huhtanen et al., 2003). Accordingly, Vaga and Huhtanen (2018) observed that dried grass contributed to a greater extent than ensiled grass to the provision of ammonia for microbial protein synthesis.

Chemical composition, instrumental color, and texture of Caciocavallo cheese are given in Table 3. No effect of diet was observed on cheese moisture that, as expected, decreased from 30 to $90 \mathrm{~d}$ of ripening $(P<$ $0.05)$. As in raw milk, the protein content was higher in $\mathrm{H}$ cheese $(P<0.05)$, whereas fat content was not affected by diet or by ripening.

A strong influence of forage preservation method on color was found with the $\mathrm{S}$ cheeses presenting higher values of lightness $(P<0.05)$, redness, yellowness, and YI $(P<0.001)$. The main effect of ripening time was observed for lightness that regularly decreased until 60 $\mathrm{d}$, reflecting the relative moisture reduction. The YI value significantly $(P<0.01)$ increased from 30 to $60 \mathrm{~d}$ as a result of $\mathrm{L}$ decrease, whereas $b^{*}$ did not vary, and $a^{*}$ value did not display a regular trend. No significant effects of diet were observed for instrumental texture, with the exception of springiness, which was significantly higher in the $\mathrm{S}$ cheeses $(P<0.001)$. Conversely, from 30 to $90 \mathrm{~d}$, hardness, springiness, and chewiness declined $(P<0.01)$, although differences between 60 and $90 \mathrm{~d}$ were significant only for chewiness $(P<0.05)$.

The cheese fatty acid composition was not influenced by the diet (Table 4). Although no studies are currently available about the effect of preservation methods on cheese fatty acids, results on milk showed a small effect (Ferlay et al., 2006; Villeneuve et al., 2013). Fatty acid profile of Caciocavallo did not change during ripening as also reported by Buccioni et al. (2012), Bonanno et al. (2013), and Esposito et al. (2014).

\section{Sensory Profile and Consumer Liking}

One relevant finding to emerge from this study is that panel training was effective as the interaction of 
Table 3. Chemical composition, and instrumental color and texture of Caciocavallo cheese (LSM \pm SEM) produced using TMR based on sorghum hay and silage during ripening ${ }^{1}$

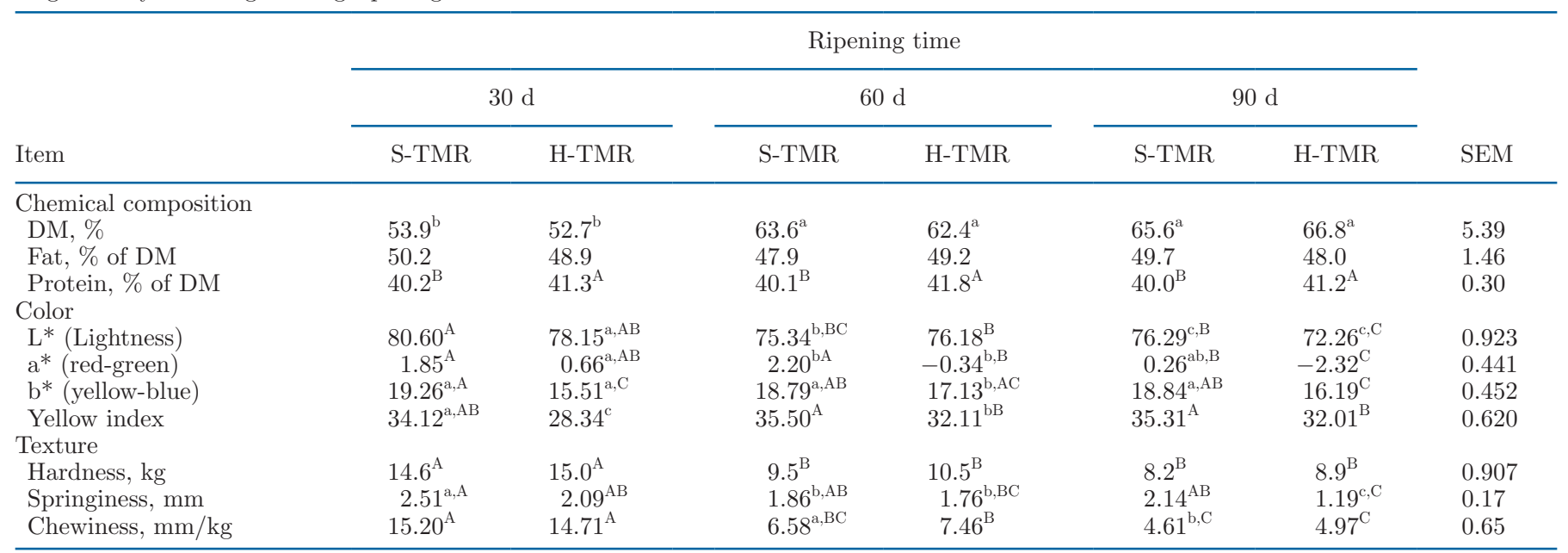

$\overline{\mathrm{A}-\mathrm{C}, \mathrm{a}-\mathrm{C}}$ Means within a row with different uppercase and lowercase superscripts are significantly different at $P<0.001$ and $P<0.05$, respectively. ${ }^{1} \mathrm{H}-\mathrm{TMR}=$ diet containing sorghum hay as sole forage source; S-TMR = diet containing sorghum silage as main forage source $(59 \%$ as fed).

product by replication was never significant, whereas the interactions assessor $\times$ product and assessor $\times$ replication were only significant for the attributes "overall odor" and odor/flavor "milk." For these 2 attributes a mixed ANOVA was performed, as detailed in the section on statistical analysis of Braghieri et al. (2016). Table 5 shows the sensory profile of cheese as affected by diet and ripening time. All of the attributes were influenced by the diet $(P<0.05)$ apart from the overall odor and the odor/flavor "milk"; the ripening time in- fluenced all of the attributes $(P<0.05)$ apart from the overall odor and the odor/flavors "milk" and "grass"; the interaction of diet $\times$ ripening time affected the appearance attributes "yellow" and "uniformity" $(P<$ $0.01)$, the overall flavor $(P<0.05)$, the taste attribute "bitter" $(P<0.001)$, and the texture attribute "tenderness" $(P<0.01)$.

The intensity of the attribute "yellow" as perceived by panelists was lower in $\mathrm{H}$ cheeses than in $\mathrm{S}$ cheeses $(P<0.01)$. This result is in agreement with both our

Table 4. Fatty acid composition (\% of total fatty acid) of Caciocavallo cheese (LSM \pm SEM) produced using TMR based on sorghum hay and silage at 30,60 , and $90 \mathrm{~d}$ of ripening ${ }^{1}$

\begin{tabular}{|c|c|c|c|c|c|c|c|}
\hline Fatty acid & \multicolumn{6}{|c|}{ Ripening time } & SEM \\
\hline $\mathrm{C} 4: 0$ & 4.64 & 4.82 & 4.88 & 4.79 & 4.32 & 4.49 & 0.36 \\
\hline C6:0 & 3.0 & 2.91 & 3.07 & 3.11 & 2.95 & 3.15 & 0.33 \\
\hline $\mathrm{C} 8: 0$ & 1.87 & 1.95 & 1.76 & 1.72 & 1.95 & 1.49 & 0.29 \\
\hline C14:0 & 12.91 & 12.78 & 13.15 & 12.96 & 13.25 & 12.44 & 0.97 \\
\hline C14:1 & 1.04 & 1.11 & 1.00 & 1.06 & 0.88 & 0.96 & 0.21 \\
\hline C15:0 & 1.12 & 1.19 & 1.23 & 1.24 & 0.97 & 1.15 & 0.19 \\
\hline C16:0 & 36.00 & 36.60 & 35.81 & 36.48 & 35.95 & 36.92 & 1.00 \\
\hline C16:1 & 1.62 & 1.59 & 1.60 & 1.49 & 1.63 & 1.59 & 0.13 \\
\hline $\mathrm{C} 17: 0$ & 0.59 & 0.60 & 0.56 & 0.49 & 0.49 & 0.57 & 0.01 \\
\hline $\mathrm{C} 17: 1$ & 0.27 & 0.30 & 0.34 & 0.33 & 0.32 & 0.31 & 0.04 \\
\hline C18:3n-3 & 0.34 & 0.33 & 0.36 & 0.33 & 0.36 & 0.36 & 0.03 \\
\hline CLA cis-9,trans-11 & 0.30 & 0.33 & 0.32 & 0.31 & 0.33 & 0.34 & 0.03 \\
\hline Others & 0.57 & 0.51 & 0.68 & 0.60 & 0.70 & 0.68 & 0.10 \\
\hline
\end{tabular}

${ }^{1} \mathrm{H}-\mathrm{TMR}=$ diet containing sorghum hay as sole forage source; S-TMR = diet containing sorghum silage as main forage source (59\% as fed). 
Table 5. Perceived intensities of sensory attributes and consumer liking of Caciocavallo cheese produced using TMR based on sorghum hay and sorghum silage at 30,60 , and $90 \mathrm{~d}_{\text {of }}$ ripening ${ }^{1}$

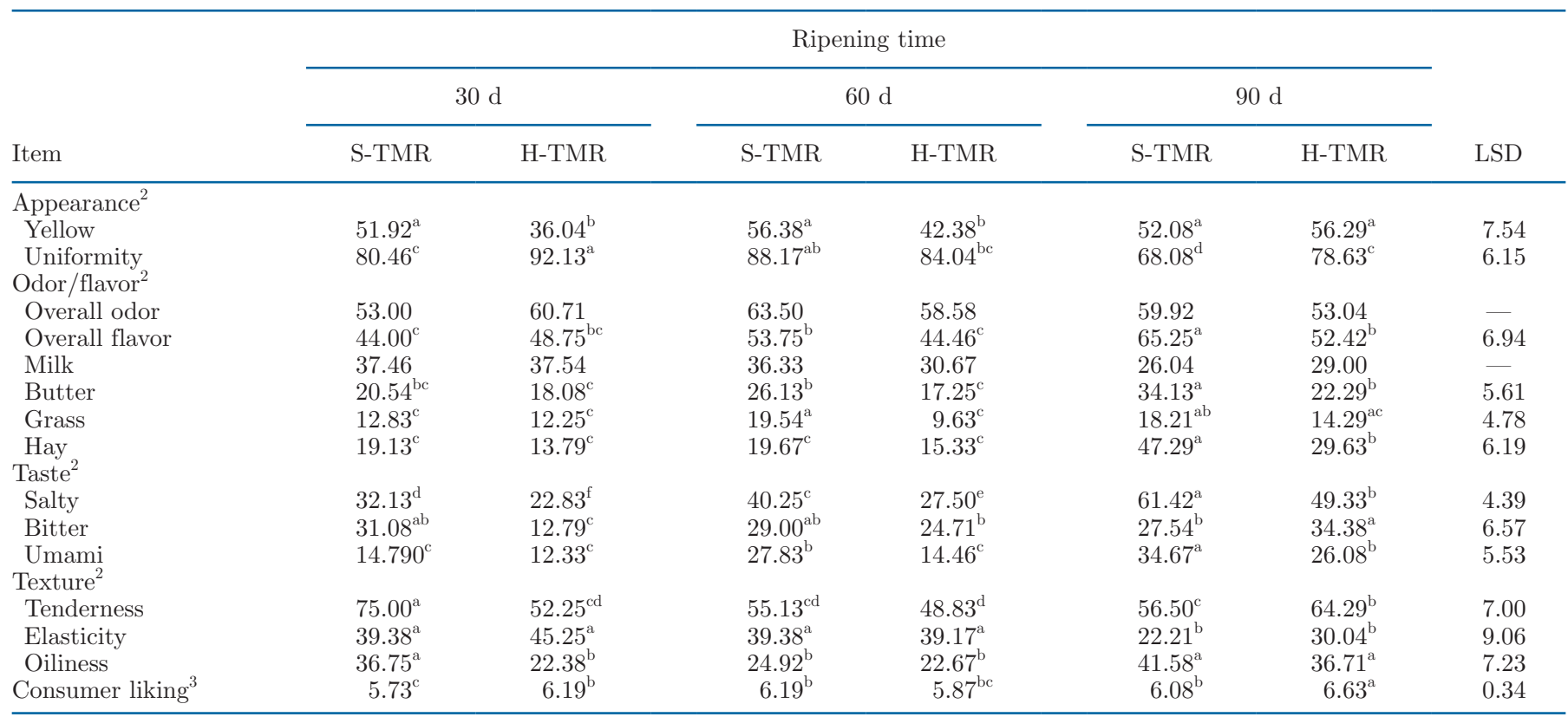

${ }^{\mathrm{a}-\mathrm{f}}$ Means within a row with different superscripts differ $(P<0.05)$.

${ }^{1} \mathrm{H}-\mathrm{TMR}=$ diet containing sorghum hay as sole forage source; $\mathrm{S}-\mathrm{TMR}=$ diet containing sorghum silage as main forage source $(59 \%$ as fed).

${ }^{2}$ Scores were given by an 8-member trained panel.

${ }^{3}$ Scores were given by a 75 -member untrained consumer panel.

instrumental findings (Table 3) and previous studies conducted on the effect of the diet on product quality (Agabriel et al., 1999; Verdier-Metz et al., 2005). Color differences in milk and cheese related to forage species or forage preservation are due to different amounts of carotenoids (Nozière et al., 2006). In particular, cheeses manufactured with milk from grass silage are markedly more yellow than those made with hay milk when the hay is left on the ground for a long time, whereas silage making better preserves carotenes (Coulon et al., 2004; Nozière et al., 2006).

In agreement with Papetti and Carelli (2013), ripening determined a gradual increment of the attribute "yellow" from 30 to 60 and $90 \mathrm{~d}(P<0.05)$. Although only partially sustained by our instrumental findings, this result is supported by other studies showing that the $b^{*}$ index (yellowness) increases during cheese ripening (El-Nimr et al., 2010; Jung et al., 2013; Nedomová et al., 2017). These changes in color may be due to the chemical modifications occurring during ripening, such as proteolysis of casein, which becomes less white, and the prevalence of reflecting components, such as riboflavin (Johnson, 1999). Color is an important appearance attribute for food products as consumers associate certain colors with certain flavors (Wadhwani and McMahon, 2012). In addition, color affects food identification and may produce expectations influenc- ing consumers' liking (Hutchings, 2003; Delwiche, 2004). The attribute "yellow," however, was not different between diet groups at 90 ripening days, possibly because the effect of ripening prevailed on the effect of the diet over such a long ripening period.

The other appearance attribute "uniformity" was perceived as more intense in $\mathrm{H}$ cheese $(P<0.01)$ as a possible consequence of the microbial activity, which characterized the production of these cheeses. Giello et al. (2017) in the same cheese samples observed that the 2 products were characterized by different microbiota. Accordingly, Coppola et al. (1990) and, more recently, Braghieri et al. (2018) observed that pasta filata cheeses obtained with different starter cultures could be differentiated on the basis of their visual characteristics. "Uniformity" significantly decreased from 60 to $90 \mathrm{~d}$ of ripening $(P<0.001)$, whereas no differences were observed between 30 and 60 ripening days. This reduction can be attributed to the natural process of aging involving microbial activity (formation of holes) and leading to a lower water content (formation of cracks). The significant diet $\times$ ripening interaction was due to the fact that no difference was observed between the 2 diet groups at 60 ripening days.

The attribute "overall flavor" was perceived as more intense in products $\mathrm{S}$ as compared with $\mathrm{H}$ products $(P<0.05)$. In addition, most of the other flavor at- 
tributes, such as "butter," "grass," and "hay," showed higher intensities in $\mathrm{S}$ cheeses than in $\mathrm{H}$ cheeses $(P$ $<0.001)$. Conversely, in Cantal cheese, which is not a pasta filata cheese, Verdier-Metz et al. (2005) observed higher intensities of the flavor attributes butter, grass, and hay when the animals were fed hay compared with cheeses produced with milk obtained from silage-fed animals.

Ripening significantly affected "overall flavor" $(P<$ 0.001 ) and the flavor attributes "butter" and "hay," with higher intensities at $90 \mathrm{~d}$ of maturation as compared with 30 and $60 \mathrm{~d}(P<0.001)$. Similar results were obtained by Fresno and Álvarez (2012) in Majorero goat cheese, whereas in Gouda cheese Jung et al. (2013) observed a reduction of butter flavor during ripening. The significant interaction diet $\times$ ripening can be attributed to the significant gradual increase of the "overall flavor" from 30 to 60 and $90 \mathrm{~d}$ of ripening in $\mathrm{S}$ products $(P<0.05)$, whereas in $\mathrm{H}$ products this attribute increased significantly only at $90 \mathrm{~d}$ as compared with 30 and $60 \mathrm{~d}$ of ripening $(P<0.05)$. Ripening is a very complex process involving microbiological and biochemical modifications (McSweeney, 2004). Proteolysis leads to the formation of a large number of peptides, further degraded to small peptides and free amino acids (FAA). Amino acid catabolism is the major process involved in flavor formation and cheese characterization due to specific FAA patterns (Niro et al., 2017). In addition, the characteristic aroma of ripened cheeses may be extremely variable, due to the influence of the enzymatic activities of indigenous or added microorganisms (Oliszewski et al., 2013), such as nonstarter lactic acid bacteria (Gobbetti et al., 2015; Guarrasi et al., 2017).

As for taste attributes, "salty" $(P<0.001)$, "bitter" $(P<0.05)$, and "umami" $(P<0.001)$ were perceived with higher intensities in $\mathrm{S}$ cheeses than in $\mathrm{H}$ products. A higher bitterness in cheeses made using milk from silage-fed animals compared with those made from hayfed animals was also reported by Coulon et al. (2004). In agreement with Fresno and Álvarez (2012) and Jung et al. (2013), these taste attributes increased throughout ripening $(P<0.05)$. As also reported for flavor and odor, proteolysis plays a major role in determining taste changes of the ripened cheese following a similar microbiological degradation pattern, which leads to the formation of smaller peptides and FAA (Fox et al., 1993; Fallico et al., 2005). Bitterness, in particular, is linked to the accumulation of bitter-tasting peptides deriving from proteolysis and peptidolysis (Smit et al., 2000; Sousa et al., 2001). The significant diet $\times$ ripening interaction observed for "bitterness" can be attributed to the fact that for $\mathrm{S}$ cheese the high perceived intensity of this attribute did not change throughout the ripening period, whereas for $\mathrm{H}$ cheese it steadily increased from low levels at $30 \mathrm{~d}$ to medium at $60 \mathrm{~d}$ and high at $90 \mathrm{~d}$ of ripening $(P<0.05)$. This result may be explained on the basis of the different microbiological activity observed in the 2 cheeses, possibly more intense from the beginning of the ripening period in $\mathrm{S}$ cheese.

Numerous authors noted that the perceived intensity of both "salty" (Barlow et al., 1989; Muir et al., 1995) and "umami" attributes (Young et al., 2004; Drake et al., 2007) increases with increasing ripening time. This result can be attributed to the reduction of moisture (see Table 3) and the consequent increment of salt and glutamate concentrations in the cheese (Fresno and Álvarez, 2012).

Diet tended to influence "tenderness" $(P<0.10)$, with higher perceived intensities in $\mathrm{S}$ cheeses than in $\mathrm{H}$ cheese. Verdier-Metz et al. (2005), due to the different textural properties of the Cantal cheese, did not record tenderness. However, these authors noted a lower perceived melting texture in cheese manufactured by using milk from silage-fed animals than in cheese obtained from hay-fed cows. These authors attributed their results to the higher proportion of low-meltingpoint fatty acids detected in milk from hay-fed animals. However, these different results are not necessarily in contrast as in our study little differences were observed between products in terms of fatty acid profile, whereas a high microbial activity was observed in S cheese (Giello et al., 2017), which may have induced the softening of the product. Cheese softening is often due to the hydrolysis of the casein micelle by proteolysis and to the reduction of the water-binding ability caused by pH changes (McSweeney, 2004). The significant effects of the ripening time and the interaction ripening time $x$ diet inducing unpredictable trends may be due to the combination of the concurrent but contrasting effects of microbiological activity and loss of water, leading to softening and toughening, respectively.

In agreement with Fresno and Álvarez (2012), elasticity decreased with ripening time $(P<0.001)$, supporting instrumental results (Table 3). Gwartney et al. (2002) attributed this effect to the higher fat content of ripened cheeses, although a reduced water content may have also played a role.

Oiliness showed higher perceived intensities in $\mathrm{S}$ cheese as compared with $\mathrm{H}$ products $(P<0.001)$, although no significant differences in fat content were observed between chemical composition of $\mathrm{H}$ and $\mathrm{S}$ cheeses. However, as stated for other attributes, the higher microbial activity observed in S products (Giello et al., 2017) may have affected this result. As observed in previous studies (e.g., Everard et al., 2006), oiliness perception was also affected by ripening with a pro- 
gressive increase from 30 to $90 \mathrm{~d}(P<0.001)$; again microbial activity and lipid oxidation may have played a role.

All of the 6 products were characterized by a good eating quality as they were all rated well above the neutral point (5, corresponding to neither pleasant nor unpleasant) of the assessment scale. Consumer liking (Table 5) was affected by ripening time and ripening time $\times$ diet $(P<0.05)$, whereas it only tended to be affected by diet $(P<0.10)$. Higher liking levels were observed for products ripened for $90 \mathrm{~d}$, as compared with cheese ripened for 30 and $60 \mathrm{~d}(P<0.05)$, whereas liking tended to be higher for cheese obtained from hayfed cows $(P<0.10)$. Although process characteristics may have a marked effect on pasta filata cheese liking (Braghieri et al., 2015, 2018), previous studies failed to detect differences in consumer liking for pasta filata cheeses obtained from different management, including feeding (Esposito et al., 2014) and dietary treatments (Uzun et al., 2018a). However, these results are not necessarily in contrast with ours, as in the Esposito et al. (2014) study silage was not included in any of the dietary treatments, whereas in Uzun et al. (2018a) silage was included in all dietary treatments, and silage is known to have a marked impact on cheese sensory properties (Coulon et al., 2004). The significant effect of the interaction ripening time $\times$ diet may be attributed to the different effect of ripening on $\mathrm{S}$ and $\mathrm{H}$ cheeses. In particular, in $\mathrm{S}$ cheese liking increased from 30 to 60 $\mathrm{d}$ of ripening $(P<0.05)$, with no further changes at 90 d. Conversely, in $\mathrm{H}$ cheese no differences were observed between 30 and $60 \mathrm{~d}$ of ripening, whereas a significant increment of liking was observed at $90 \mathrm{~d}$, when product $\mathrm{H}$ was scored as the most liked, in comparison with the same cheese ripened 30 and $60 \mathrm{~d}(P<0.05)$.

\section{Volatile Compounds}

The GC/MS analysis allowed the identification of 21 different volatiles in cheese (Table 6). For all the samples the most abundant volatile compounds were acids and ketones, followed by esters, alcohols, aldehydes, and hydrocarbons.

Whereas $\alpha$-pinene was identified only in the $\mathrm{H}$ cheeses, higher levels of 2,3-butanedione, 2-heptanone $(P<0.05)$, 3-hydroxy-2-butanone, hexanoic acid, and octanoic acid $(P<0.001)$ were found the $\mathrm{S}$ cheeses at both ripening times.

A large quantity of volatile compounds was produced during ripening, so that acetone and 2-ethyl-1-hexanol were higher in 60-d ripened cheeses as well as the acids (i.e., acetic acid, butanoic, hexanoic, octanoic, and

Table 6. Headspace concentrations ( $\mu \mathrm{g} / \mathrm{kg}$ ) of volatile compounds determined in Caciocavallo cheese produced using TMR based on sorghum hay and sorghum silage after 30 and $60 \mathrm{~d}$ of ripening ${ }^{1}$

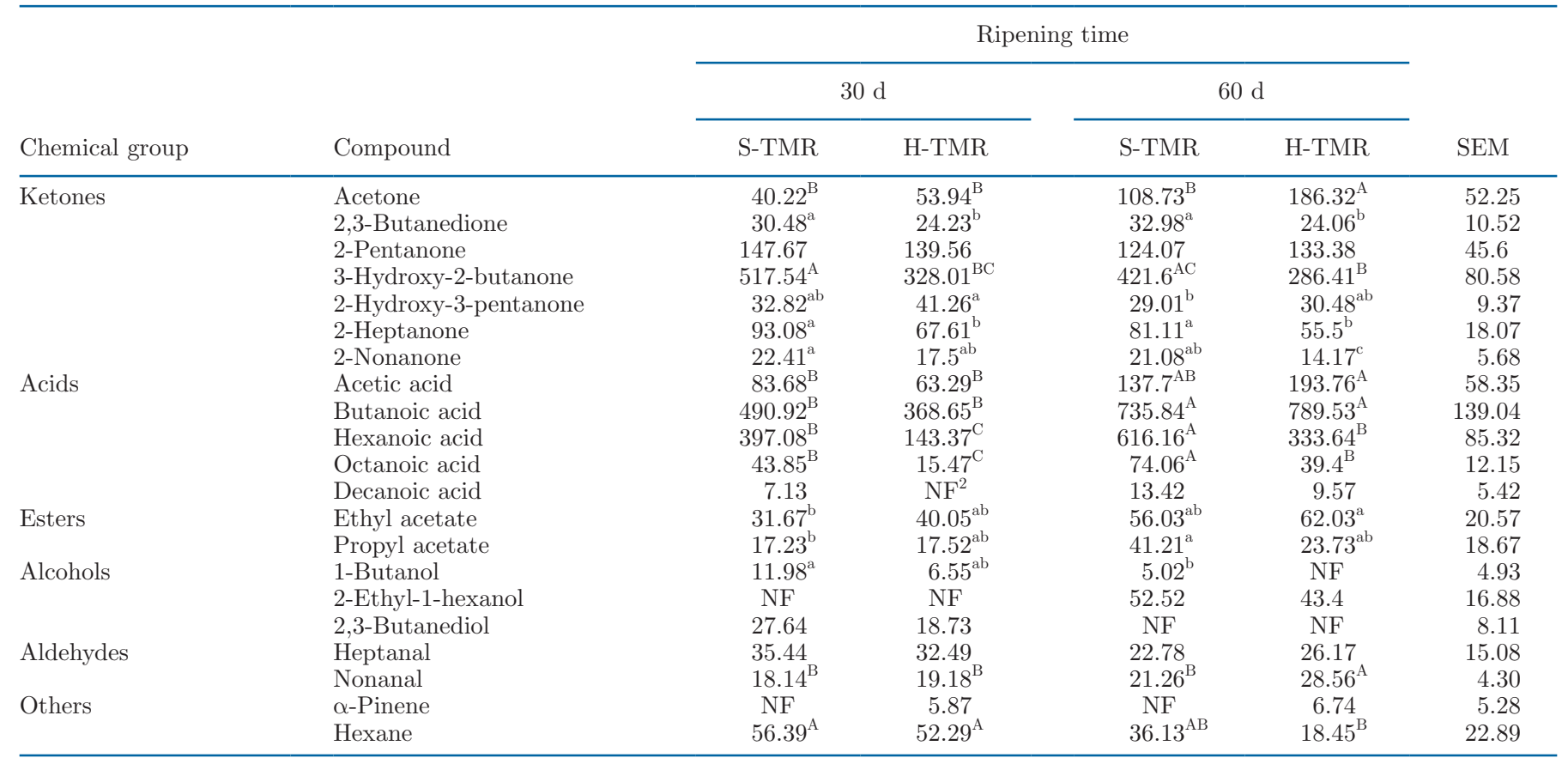

$\overline{\mathrm{A}-\mathrm{C} ; \mathrm{a}-\mathrm{c}}$ Means within a row with different uppercase and lowercase superscripts are significantly different at $P<0.001$ and $P<0.05$, respectively. ${ }^{1} \mathrm{H}-\mathrm{TMR}=$ diet containing sorghum hay as sole forage source; S-TMR = diet containing sorghum silage as main forage source $(59 \%$ as fed). ${ }^{2} \mathrm{NF}=$ compound not found. 
decanoic) possibly as an effect of lipolytic action. For 2-nonanone, propyl acetate, and nonanal, the effect of ripening was different for $\mathrm{S}$ and $\mathrm{H}$ cheeses.

Although comparisons with the existing literature may be difficult due to differences in analytic techniques, cheese-making procedures, indigenous microflora, and ripening length and conditions (FernándezGarcía et al., 2002; Stefanon and Procida, 2004), our results are in line with those reported by Stefanon and Procida (2004) in Montasio cheese. These authors noted limited effects of silage feeding on aldehydes, whereas ketones were influenced by diet and ripening. Ketones originate from AA degradation (Barbieri et al., 1994; Urbach, 1997) and are important components of cheese. Therefore, their higher content may have negatively affected the liking of $\mathrm{S}$ cheese as also observed by Moio et al. (1993). The pine note of $\alpha$-pinene was lacking in $\mathrm{S}$ cheese, while being a key compound of $\mathrm{H}$ cheese. The $\alpha$ - and $\beta$-pinenes are common terpenes of the forages and their level in milk and cheeses is higher if lactating cows are fed natural pastures or hay rather than silage fodder, as in silage terpenes decline due to the bioconversion in other compounds operated by microorganisms involved in the fermentation (Kalač, 2011). Nevertheless, Verdier-Metz et al. (1998) and Stefanon and Procida (2004) failed to find an effect of silage feeding on $\alpha$-pinene.

\section{Relationship Between Volatile Compounds and Sensory Properties}

Figure 1 shows the partial least squares regression analysis between sensory attributes and volatile compounds of cheeses. Partial least squares analysis allowed a good separation between $\mathrm{S}$ and $\mathrm{H}$ cheeses along the first axis, whereas cheeses ripened 30 and $60 \mathrm{~d}$ were separated along the second axis (Figure 1). Silage feeding and 60-d ripening induced the formation of a higher number of volatile compounds than hay feeding and $30 \mathrm{~d}$ of ripening. The sorghum silage Caciocavallo ripened for $60 \mathrm{~d}$ showed "overall flavor," the odor/ flavor attributes "butter," "hay," and "grass," and volatile compounds such as octanoic acid, decanoic acid, 2-pentanone, 2,3-butanedione, and propyl acetate. The

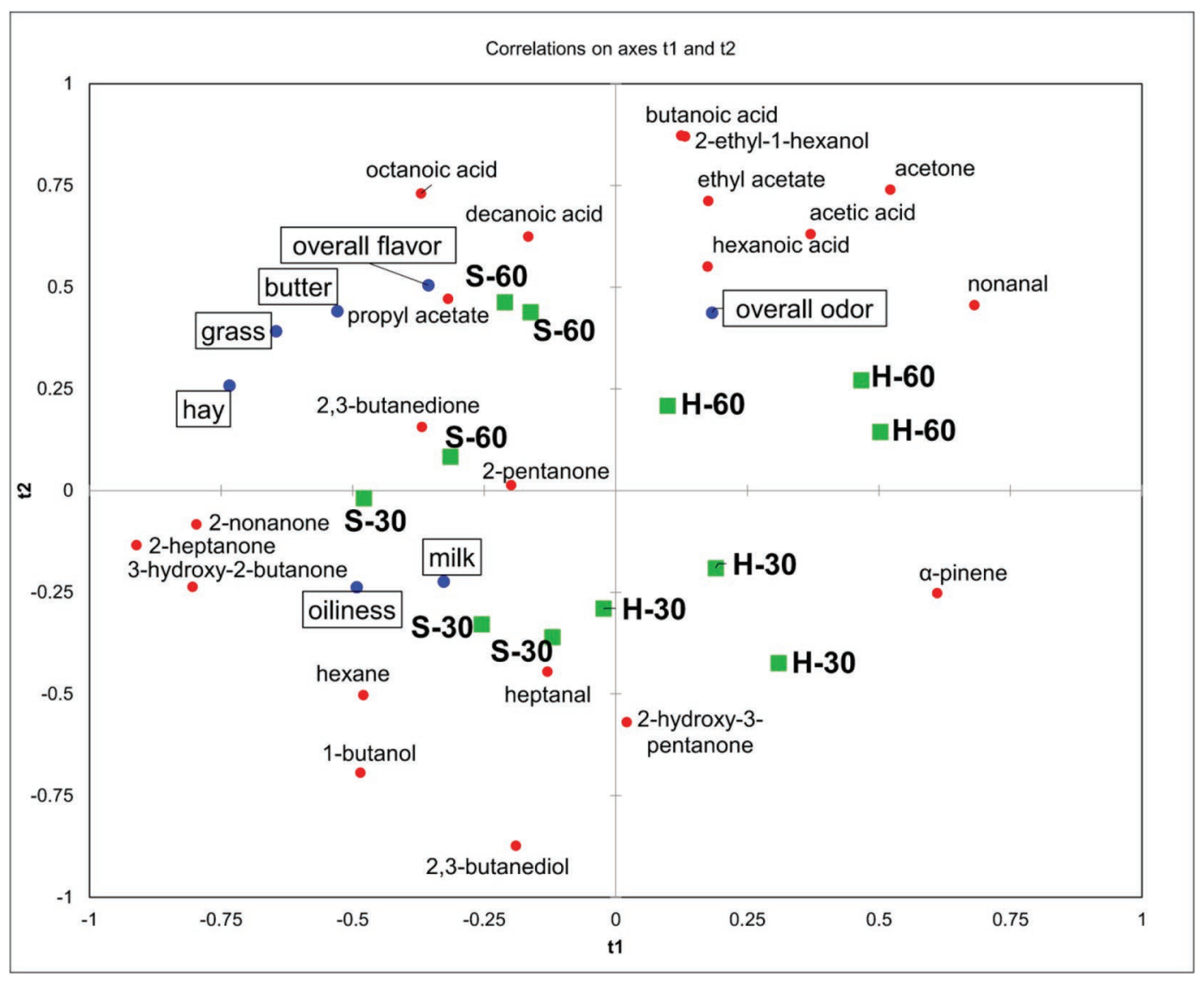

Figure 1. Partial least squares analysis for the selected GC/MS volatiles and the sensory odor descriptors. S-60 = sorghum silage Caciocavallo ripened for $60 \mathrm{~d}$; S-30 = sorghum silage Caciocavallo ripened for $30 \mathrm{~d}$; H-60 = sorghum hay Caciocavallo ripened for $60 \mathrm{~d}$; H-30 = sorghum hay Caciocavallo ripened for $30 \mathrm{~d}$. 
sorghum silage Caciocavallo ripened for $30 \mathrm{~d}$ exhibited the odor/flavor attribute "milk," the texture attribute "oiliness," and volatile compounds such as 2-nonanone, 2-heptanone, 3-hydroxy-2-butanone, hexane, 1-butanol, heptanal, 2-hydroxy-3-pentanone, and 2,3-butandiol. In particular, the "butter" note seems to be correlated to 2,3-butandione (diacetyl), the attribute "milk" to 3-hydroxy-2-butanone, and the texture "oiliness" to 2-heptanone and 2-nonanone. The $\mathrm{H}$ cheeses are located along the positive end of the first axis and are separated by the second axis according to the ripening period. The $\mathrm{H}$ cheese at $60 \mathrm{~d}$ of ripening was correlated to "overall odor," acetic acid, butanoic acid, hexanoic acid, acetone, 2-ethyl-1-hexanol, and nonanal, whereas at $30 \mathrm{~d}$ it was characterized by $\alpha$-pinene and 2 -hydroxy3-pentanone.

\section{CONCLUSIONS}

Although the use of ensiled forage did not affect the chemical composition and fatty acid profile of Caciocavallo cheese, several volatile compounds and sensory characteristics changed according to the forage preservation method and the ripening time. Ripening induced increased levels of the appearance attribute "yellowness," along with the "overall flavor," the odor/flavor attributes "butter" and "hay," the "salty," "bitter," and "umami" tastes, and the texture attribute "oiliness," whereas the appearance attribute "uniformity" and the texture attribute "elasticity" were reduced. A silagebased diet induced higher perceived intensity of several attributes such as "yellowness" appearance, "overall flavor," "butter," "grass" and "hay" odor/flavors, "salty," "bitter" and "umami" tastes, "tenderness," and "oiliness" textures. In S cheese we also observed higher amounts of ketones and acids. Conversely, $\mathrm{H}$ cheese showed the terpene $\alpha$-pinene, which was not detected in $\mathrm{S}$ cheese, and a higher intensity of the appearance attribute "uniformity." These differences allowed the trained panel to discriminate the products and determined an increased consumer liking for hay cheese at 30 and $90 \mathrm{~d}$ of ripening, thus supporting a differentiation marketing strategy for Caciocavallo cheese sold with the TSG label "Haymilk."

\section{ACKNOWLEDGMENTS}

The study was supported by Campania Region, PSR 2007-2013 Misura 124, project CEREAMICO (Italy). The authors express their appreciation to Maria Luisa Varricchio for valuable assistance during cheese-making and sample collection, Andrea Marrazzo for the technical support during the volatile compound analysis (both of Department of Agricultural Science, University Federico II, Naples, Italy), and to the staff of the farm "Antonio Pacifico" (Castelfranco in Miscano, Italy) for the hospitality and useful support in animals care.

\section{REFERENCES}

Agabriel, C., J. B. Coulon, C. Journal, C. Sibra, and H. Albouy. 1999. Variabilité des caractéristiques des fromages saint-nectaire fermiers: Relations avec la composition du lait et les conditions de production. Lait 79:291-302. https://doi.org/10.1051/lait:1999325.

Albenzio, M., A. Santillo, M. Caroprese, A. Braghieri, A. Sevi, and F. Napolitano. 2013. Composition and sensory profiling of probiotic Scamorza ewe milk cheese. J. Dairy Sci. 96:2792-2800. https://doi .org/10.3168/jds.2012-6273.

AOAC International. 2002. Official Methods of Analysis. 17th ed. AOAC International, Gaithersburg, MD.

Barbieri, G., L. Bolzoni, M. Careri, A. Mangia, G. Parolari, S. Spagnoli, and R. Virgili. 1994. Study of the volatile fraction of Parmesan cheese. J. Agric. Food Chem. 42:1170-1176. https://doi.org/ 10.1021/jf00041a023.

Barlow, I., G. T. Lloyd, E. H. Ramshaw, A. J. Miller, G. P. McCabe, and L. McCabe. 1989. Correlations and changes in flavour and chemical parameters of cheddar cheeses during maturation. Aust. J. Dairy Technol. 44:7-18.

Bonanno, A., G. Tornambè, V. Bellina, C. De Pasquale, F. Mazza, G. Maniaci, and A. Di Grigoli. 2013. Effect of farming system and cheesemaking technology on the physicochemical characteristics, fatty acid profile, and sensory properties of Caciocavallo Palermitano cheese. J. Dairy Sci. 96:710-724. https://doi.org/10.3168/jds .2012-5973.

Borreani, G., D. Giaccone, A. Mimosi, and E. Tabacco. 2007. Comparison of hay and haylage from permanent alpine meadows in winter dairy cow diets. J. Dairy Sci. 90:5643-5650. https://doi .org/10.3168/jds.2007-0134.

Braghieri, A., N. Piazzolla, F. Galgano, N. Condelli, G. De Rosa, and F. Napolitano. 2016. Effect of preservative addition on sensory and dynamic profile of Lucanian dry-sausages as assessed by quantitative descriptive analysis and temporal dominance of sensations. Meat Sci. 122:68-75. https://doi.org/10.1016/j.meatsci.2016.07 .020 .

Braghieri, A., N. Piazzolla, A. Romaniello, F. Paladino, A. Ricciardi, and F. Napolitano. 2015. Effect of adjuncts on sensory properties and consumer liking of Scamorza cheese. J. Dairy Sci. 98:14791491. https://doi.org/10.3168/jds.2014-8555.

Braghieri, A., T. Zotta, G. Morone, N. Piazzolla, M. Majlesi, and F. Napolitano. 2018. Starter cultures and preservation liquids modulate consumer liking and shelf life of mozzarella cheese. Int. Dairy J. 85:254-262. https://doi.org/10.1016/j.idairyj.2018.06.013.

Buccioni, A., S. Minieri, G. Conte, D. Benvenuti, A. Pezzati, M. Antongiovanni, S. Rapaccini, and M. Mele. 2012. Changes in conjugated linoleic acid and C18:1 isomers profile during the ripening of Pecorino Toscano cheese produced with raw milk. Ital. J. Anim. Sci. 11:e75. https://doi.org/10.4081/ijas.2012.e75.

Coblentz, W. K., and M. S. Akins. 2018. Silage review: Recent advances and future technologies for baled silages. J. Dairy Sci 101:4075-4092. https://doi.org/10.3168/jds.2017-13708.

Coppola, S., F. Villani, R. Coppola, and E. Parente. 1990. Comparison of different starter systems for water-buffalo Mozzarella cheese manufacture. Lait 70:411-423. https://doi.org/10.1051/lait:19905 -631 .

Cosentino, C., D. Faraone, R. Paolino, P. Freschi, and M. Musto. 2016. Short communication: Sensory profile and acceptability of a cow milk cheese manufactured by adding jenny milk. J. Dairy Sci. 99:228-233. https://doi.org/10.3168/jds.2015-10107.

Coulon, J. B., A. Delacroix-Buchet, B. Martin, and A. Pirisi. 2004. Relationships between ruminant management and sensory characteristics of cheeses: A review. Lait 84:221-241. https://doi.org/10 .1051/lait:2004008 
Delwiche, J. 2004. The impact of perceptual interactions on perceived flavor. Food Qual. Prefer. 15:137-146. https://doi.org/10.1016/ S0950-3293(03)00041-7.

Drake, S. L., M. E. C. Carunchia Whetstine, M. A. Drake, P. Courtney, K. Fligner, J. Jenkins, and C. Pruitt. 2007. Sources of umami taste in Cheddar and Swiss cheeses. J. Food Sci. 72:S360-S366. https://doi.org/10.1111/j.1750-3841.2007.00402.x.

Driehuis, F., J. M. Wilkinson, Y. Jiang, I. Ogunade, and A. T. Adesogan. 2018. Silage review: Animal and human health risks from silage. J. Dairy Sci. 101:4093-4110. https://doi.org/10.3168/jds 2017-13836.

El-Nimr, A. A., H. A. Eissa, M. M. El-Abd, A. A. Mehriz, H. M. Abbas, and H. M. Bayoumi. 2010. Water activity, color characteristics and sensory properties of Egyptian Gouda cheese during ripening. J. Am. Sci. 6:447-453.

Esposito, G., F. Masucci, F. Napolitano, A. Braghieri, R. Romano, N. Manzo, and A. Di Francia. 2014. Fatty acid and sensory profiles of Caciocavallo cheese as affected by management system. J. Dairy Sci. 97:1918-1928. https://doi.org/10.3168/jds.2013-7292.

European Commission. 2016. Commission Implementing Regulation (EU) 2016/304 of 2 March 2016 entering a name in the register of traditional specialities guaranteed (Heumilch/Haymilk/Latte fieno/Lait de foin/Leche de heno (TSG)). Official Journal of the European Union 58:28-34.

Everard, C. D., D. J. O'Callaghan, T. V. Howard, C. P. O'Donnell, E. M. Sheehan, and C. M. Delahunty. 2006. Relationships between sensory and rheological measurements of texture in maturing commercial Cheddar cheese over a range of moisture and $\mathrm{pH}$ at the point of manufacture. J. Texture Stud. 37:361-382. https://doi .org/10.1111/j.1745-4603.2006.00057.x

Fallico, V., P. L. H. McSweeney, J. Horne, C. Pediliggieri, J. A. Hannon, S. Carpino, and G. Licitra. 2005. Evaluation of bitterness in Ragusano cheese. J. Dairy Sci. 88:1288-1300. https://doi.org/10 .3168/jds.S0022-0302(05)72795-8.

Ferlay, A., B. Martin, P. Pradel, J. B. Coulon, and Y. Chilliard. 2006. Influence of grass-based diets on milk fatty acid composition and milk lipolytic system in Tarentaise and Montbéliarde cow breeds. J. Dairy Sci. 89:4026-4041. https://doi.org/10.3168/jds.S0022 -0302(06)72446-8.

Fernández-García, E., M. Carbonell, and M. Nuñez. 2002. Volatile fraction and sensory characteristics of Manchego cheese. Comparison of raw and pasteurized milk cheese. J. Dairy Res. 69:579-593. https://doi.org/10.1017/s0022029902005794.

Fox, P. F., T. M. Cogan, and T. P. Guinee. 2017. Factors that affect the quality of cheese. Pages 617-641 in Cheese: Chemistry, Physics and Microbiology. Vol. 2. Cheese Technology and Major Cheese Groups. P. L. H. McSweeney, P. F. Fox, P. D. Cotter, and D. W. Everett, ed. Academic Press, San Diego, CA.

Fox, P. F., J. Law, P. L. H. McSweeney, and J. Wallace. 1993. Biochemistry of cheese ripening. Pages 389-438 in Cheese: Chemistry, Physics and Microbiology. P. F. Fox, ed. Springer, New York, NY.

Francis, F. J., and F. M. Clydesdale. 1975. Food Colorimetry: Theory and Applications. Avi Publishing Co. Inc., Westport, CT.

Freschi, P., M. Musto, R. Paolino, and C. Cosentino. 2015. Grazing and biodiversity conservation: Highlights on a natura 2000 network site. Pages $271-288$ in The Sustainability of Agro-Food and Natural Resource Systems in the Mediterranean Basin. A. Vastola, ed. Springer International Publishing, New York, NY.

Fresno, M., and S. Álvarez. 2012. Chemical, textural and sensorial changes during the ripening of Majorero goat cheese. Int. J. Dairy Technol. 65:393-400. https://doi.org/10.1111/j.1471-0307.2012 $.00842 . \mathrm{x}$.

Genovese, A., A. Marrazzo, L. De Luca, R. Romano, N. Manzo, F. Masucci, A. Di Francia, and R. Sacchi. 2019. Volatile organic compound and fatty acid profile of milk from cows and buffaloes fed mycorrhizal or nonmycorrhizal ensiled forage. Molecules 24:1616. https://doi.org/10.3390/molecules24081616.

Giaccone, D., A. Revello-Chion, L. Galassi, P. Bianchi, G. Battelli, M. Coppa, E. Tabacco, and G. Borreani. 2016. Effect of milk thermisation and farming system on cheese sensory profile and fatty acid composition. Int. Dairy J. 59:10-19. https://doi.org/10.1016/ j.idairyj.2016.02.047.

Giello, M., A. La Storia, F. Masucci, A. Di Francia, D. Ercolini, and F. Villani. 2017. Dynamics of bacterial communities during manufacture and ripening of traditional Caciocavallo of Castelfranco cheese in relation to cows' feeding. Food Microbiol. 63:170-177. https:// doi.org/10.1016/j.fm.2016.11.016.

Glasser, F., M. Doreau, G. Maxin, and R. Baumont. 2013. Fat and fatty acid content and composition of forages: A meta-analysis. Anim. Feed Sci. Technol. 185:19-34. https://doi.org/10.1016/j .anifeedsci.2013.06.010.

Gobbetti, M., M. De Angelis, R. Di Cagno, L. Mancini, and P. F. Fox. 2015. Pros and cons for using non-starter lactic acid bacteria (NSLAB) as secondary/adjunct starters for cheese ripening. Trends Food Sci. Technol. 45:167-178. https://doi.org/10.1016/j tifs.2015.07.016

Guarrasi, V., C. Sannino, M. Moschetti, A. Bonanno, A. Di Grigoli, and L. Settanni. 2017. The individual contribution of starter and non-starter lactic acid bacteria to the volatile organic compound composition of Caciocavallo Palermitano cheese. Int. J. Food Microbiol. 259:35-42. https://doi.org/10.1016/j.ijfoodmicro.2017.07 .022 .

Gwartney, E. A., E. A. Foegeding, and D. K. Larick. 2002. The texture of commercial full-fat and reduced-fat cheese. J. Food Sci. 67:812-816. https://doi.org/10.1111/j.1365-2621.2002.tb10682.x.

Hancock, D. W., and M. Collins. 2006. Forage preservation method influences alfalfa nutritive value and feeding characteristics. Crop Sci. 46:688-694. https://doi.org/10.2135/cropsci2005.0183.

Huhtanen, P., J. I. Nousiainen, H. Khalili, S. Jaakkola, and T. Heikkilä. 2003. Relationships between silage fermentation characteristics and milk production parameters: Analyses of literature data. Livest. Prod. Sci. 81:57-73. https://doi.org/10.1016/S0301 $-6226(02) 00195-1$.

Hutchings, J. B. 2003. Expectations and the Food Industry: The Impact of Color and Appearance. Kluwer Academic/Plenum Publisher, New York, NY.

ISO. 1998. Sensory analysis-General guidance for the design of test rooms. ISO 8589:1998. International Organization for Standardization, Geneva, Switzerland.

ISO. 2000. Animal feeding stuffs. Determination of starch content-Polarimetric method. ISO 6493:2000. International Organization for Standardization Geneva, Switzerland.

Johnson, M. 1999. Casein - How it colors cheese. UW Dairy Pipeline $11: 1-7$

Jung, H. J., E. J. Ko, and H. S. Kwak. 2013. Comparison of physicochemical and sensory properties between cholesterol-removed gouda cheese and gouda cheese during ripening. Asian-Australas. J. Anim. Sci. 26:1773-1780. https://doi.org/10.5713/ajas.2013 .13255 .

Kähkönen, P., H. Tuorila, and H. Rita. 1996. How information enhances acceptability of a low-fat spread. Food Qual. Prefer. 7:87-94 https://doi.org/10.1016/0950-3293(95)00040-2.

Kalač, P. 2011. The effects of silage feeding on some sensory and health attributes of cow's milk: A review. Food Chem. 125:307-317. https: //doi.org/10.1016/j.foodchem.2010.08.077.

Kalač, P., and E. Samková. 2010. The effects of feeding various forages on fatty acid composition of bovine milk fat: A review. Czech J. Anim. Sci. 55:521-537. https://doi.org/10.17221/2485-CJAS.

Khan, N. A., P. Yu, M. Ali, J. W. Cone, and W. H. Hendriks. 2015. Nutritive value of maize silage in relation to dairy cow performance and milk quality. J. Sci. Food Agric. 95:238-252. https:// doi.org/10.1002/jsfa.6703.

Lee, J. H., R. Diono, G. Y. Kim, and D. B. Min. 2003. Optimization of solid phase microextraction analysis for the headspace volatile compounds of Parmesan cheese. J. Agric. Food Chem. 51:11361140. https://doi.org/10.1021/jf025910+.

Licitra, G., T. M. Hernandez, and P. J. Van Soest. 1996. Standardization of procedures for nitrogen fractionation of ruminant feeds. Anim. Feed Sci. Technol. 57:347-358. https://doi.org/10.1016/ 0377-8401(95)00837-3. 
Martin, B., C. Hurtaud, B. Graulet, A. Ferlay, Y. Chilliard, and J. B. Coulon. 2009. Grass and the nutritional and organoleptic qualities of dairy products. Fourrages (Versailles) 199:291-310.

Martin, B., I. Verdier-Metz, S. Buchin, C. Hurtaud, and J. B. Coulon. 2005. How do the nature of forages and pasture diversity influence the sensory quality of dairy livestock products? Anim. Sci. 81:205-212. https://doi.org/10.1079/ASC50800205.

Martineau, R., H. Lapierre, D. R. Ouellet, D. Pellerin, and R. Berthiaume. 2007. Effects of the method of conservation of timothy on nitrogen metabolism in lactating dairy cows. J. Dairy Sci. 90:28702882. https://doi.org/10.3168/jds.2006-763.

McSweeney, P. L. H. 2004. Biochemistry of cheese ripening. Int. J. Dairy Technol. 57:127-144. https://doi.org/10.1111/j.1471-0307 2004.00147.x.

Moio, L., J. Dekimpe, P. X. Etievant, and F. Addeo. 1993. Volatile flavour compounds of water buffalo Mozzarella cheese. Ital. J. Food Sci. 5:57-68.

Mordenti, A. L., N. Brogna, and A. Formigoni. 2017. Review: The link between feeding dairy cows and Parmigiano-Reggiano cheese production area. Prof. Anim. Sci. 33:520-529. https://doi.org/10 $.15232 /$ pas.2016-01602.

Muir, D. D., E. A. Hunter, J. M. Banks, and D. S. Horne. 1995. Sensory properties of Cheddar cheese: Changes during maturation. Food Res. Int. 28:561-568. https://doi.org/10.1016/0963-9969(95)00039 -9 .

Murray, J. M., C. M. Delahunty, and I. A. Baxter. 2001. Descriptive sensory analysis: Past, present and future. Food Res. Int. 34:461471. https://doi.org/10.1016/S0963-9969(01)00070-9.

Nedomová, Š., L. Kilián, R. Pytel, and V. Kumbár. 2017. Effect of ripening time on colour and texture properties in cheese. Potravinarstvo Slovak J. Food Sci. 11:296-301. https://doi.org/10.5219/ 744.

Niro, S., M. Succi, P. Tremonte, E. Sorrentino, R. Coppola, G. Panfili, and A. Fratianni. 2017. Evolution of free amino acids during ripening of Caciocavallo cheeses made with different milks. J. Dairy Sci. 100:9521-9531. https://doi.org/10.3168/jds.2017-13308.

Nozière, P., B. Graulet, A. Lucas, B. Martin, P. Grolier, and M. Doreau. 2006. Carotenoids for ruminants: From forages to dairy products. Anim. Feed Sci. Technol. 131:418-450. https://doi.org/ 10.1016/j.anifeedsci.2006.06.018.

Oliszewski, R., I. V. Wolf, C. V. Bergamini, M. Candioti, and M. C. Perotti. 2013. Influence of autochthonous adjunct cultures on ripening parameters of Argentinean goat's milk cheeses. J. Sci. Food Agric. 93:2730-2742. https://doi.org/10.1002/jsfa.6092.

Papetti, P., and A. Carelli. 2013. Composition and sensory analysis for quality evaluation of a typical Italian cheese: Influence of ripening period. Czech J. Food Sci. 31:438-444. https://doi.org/10.17221/ 447/2012-CJFS.

Paredes, C. L. L., M. Werteker, B. Rossmann, J. Keplinger, I. L. Olschewski, and M. Schreiner. 2018. Discrimination of haymilk and conventional milk via fatty acid profiles. J. Food Meas. Charact. 12:1391-1398. https://doi.org/10.1007/s11694-018-9753-0.

Piraino, P., T. Zotta, A. Ricciardi, and E. Parente. 2005. Discrimination of commercial Caciocavallo cheeses on the basis of the diversity of lactic microflora and primary proteolysis. Int. Dairy J. 15:1138-1149. https://doi.org/10.1016/j.idairyj.2004.12.006.

Romano, R., A. Giordano, L. Chianese, F. Addeo, and S. S. Musso. 2011. Triacylglycerols, fatty acids and conjugated linoleic acids in Italian Mozzarella di Bufala Campana cheese. J. Food Compos. Anal. 24:244-249. https://doi.org/10.1016/j.jfca.2010.10.004.

Sauvant, D., and P. Nozière. 2013. La quantification des principaux phénomènes digestifs chez les ruminants: Les relations utilisées pour rénover les systèmes d'unités d'alimentation énergétique et protéique. INRA Prod. Anim. 26:327-346.

Smit, G., A. Verheul, R. van Kranenburg, E. Ayad, R. Siezen, and W. Engels. 2000. Cheese flavour development by enzymatic conversions of peptides and amino acids. Food Res. Int. 33:153-160. https://doi.org/10.1016/S0963-9969(00)00029-6.
Sousa, M. J., Y. Ardö, and P. L. H. McSweeney. 2001. Advances in the study of proteolysis during cheese ripening. Int. Dairy J. 11:327345. https://doi.org/10.1016/S0958-6946(01)00062-0.

Stefanon, B., and G. Procida. 2004. Effects of including silage in the diet on volatile compound profiles in Montasio cheese and their modification during ripening. J. Dairy Res. 71:58-65. https://doi .org/10.1017/s0022029903006563.

Urbach, G. 1997. The flavour of milk and dairy products: II. Cheese: Contribution of volatile compounds. Int. J. Dairy Technol. 50:7989. https://doi.org/10.1111/j.1471-0307.1997.tb01743.x.

Uzun, P., F. Masucci, F. Serrapica, F. Napolitano, A. Braghieri, R. Romano, N. Manzo, G. Esposito, and A. Di Francia. 2018a. The inclusion of fresh forage in the lactating buffalo diet affects fatty acid and sensory profile of mozzarella cheese. J. Dairy Sci. 101:6752-6761. https://doi.org/10.3168/jds.2018-14710.

Uzun, P., F. Masucci, F. Serrapica, M. L. Varricchio, C. Pacelli, S. Claps, and A. Di Francia. 2018b. Use of mycorrhizal inoculum under low fertilizer application: Effects on forage yield, milk production, and energetic and economic efficiency. J. Agric. Sci. 156:127135. https://doi.org/10.1017/S0021859618000072.

Uzun, P., F. Serrapica, F. Masucci, B. C. M. Assunta, H. Yildiz, F. Grasso, and A. Di Francia. 2019. Diversity of traditional Caciocavallo cheeses produced in Italy. Int. J. Dairy Technol. 14710307.12640. https://doi.org/10.1111/1471-0307.12640.

Vaga, M., and P. Huhtanen. 2018. In vitro investigation of the ruminal digestion kinetics of different nitrogen fractions of $15 \mathrm{~N}$-labelled timothy forage. PLoS One 13:e0203385. https://doi.org/10.1371/ journal.pone.0203385.

Van Soest, P. J., J. B. Robertson, and B. A. Lewis. 1991. Methods for dietary fiber, neutral detergent fiber, and nonstarch polysaccharides in relation to animal nutrition. J. Dairy Sci. 74:3583-3597. https://doi.org/10.3168/jds.S0022-0302(91)78551-2.

Vanderlip, R. L., and H. E. Reeves. 1972. Growth stages of sorghum [Sorghum bicolor (L.) Moench.]. Agron. J. 64:13-16. https://doi .org/10.2134/agronj1972.00021962006400010005x.

Verdier-Metz, I., J. B. Coulon, P. Pradel, C. Viallon, and J. L. Berdagué. 1998. Effect of forage conservation (hay or silage) and cow breed on the coagulation properties of milks and on the characteristics of ripened cheeses. J. Dairy Res. 65:9-21. https://doi.org/10 $.1017 /$ S0022029997002616.

Verdier-Metz, I., B. Martin, P. Pradel, H. Albouy, S. Hulin, M. C. Montel, and J. B. Coulon. 2005. Effect of grass-silage vs. hay diet on the characteristics of cheese: Interactions with the cheese model. Lait 85:469. https://doi.org/10.1051/lait:2005032.

Villeneuve, M.-P., Y. Lebeuf, R. Gervais, G. F. Tremblay, J. C. Vuillemard, J. Fortin, and P. Y. Chouinard. 2013. Milk volatile organic compounds and fatty acid profile in cows fed timothy as hay, pasture, or silage. J. Dairy Sci. 96:7181-7194. https://doi.org/10 $.3168 /$ jds.2013-6785.

Wadhwani, R., and D. J. McMahon. 2012. Color of low-fat cheese influences flavor perception and consumer liking. J. Dairy Sci. 95:2336-2346. https://doi.org/10.3168/jds.2011-5142.

Young, N. D., M. Drake, K. Lopetcharat, and M. R. McDaniel. 2004. Preference mapping of Cheddar cheese with varying maturity levels. J. Dairy Sci. 87:11-19. https://doi.org/10.3168/jds.S0022 -0302(04)73136-7.

\section{ORCIDS}

F. Masucci ๑ https://orcid.org/0000-0003-2382-0354

F. Napolitano () https://orcid.org/0000-0002-7169-5300

A. Braghieri @ https://orcid.org/0000-0001-9824-0579

A. Genovese (으 https://orcid.org/0000-0002-9202-6122

R. Sacchi ๑ https://orcid.org/0000-0002-1040-0361

C. M. A. Barone (i) https://orcid.org/0000-0003-0433-0712

A. Di Francia ๑ https://orcid.org/0000-0002-2859-8038 